\title{
The Effect of Mnemonic Keyword Techniques Instruction on Vocabulary Achievement and vocabulary Size of Iranian EFL Learners
}

\author{
Amir Marzban, Mojgan Firoozjahantigh* \\ English Department, Islamic Azad University, Qaemshahr Branch, Qaemshahr, Iran \\ Corresponding Author: Mojgan Firoozjahantigh, E-mail: mojganfiroozjahan@gmail.com
}

\section{ARTICLE INFO}

Article history

Received: November 19, 2018

Accepted: April 25, 2018

Published: July 01, 2018

Volume: 7 Issue: 4

Advance access: March 2018

Conflicts of interest: None

Funding: None

\begin{abstract}
This study aimed at probing the effect of using mnemonic keyword techniques, a number of less used procedures, in teaching vocabulary in an EFL context in Iran on the vocabulary achievement level and vocabulary size of language learners. to this end, $70 \mathrm{EFL}$ intermediate students were selected because they were all intermediate level learners. They were assigned to control and experimental groups. The instructor taught the two groups new vocabulary items in their textbooks as part of the class procedures. The first group received vocabulary instruction through mnemonic keyword techniques while the second had vocabulary taught in conventional ways. Both groups were tested for their EFL vocabulary achievement and vocabulary size. The results revealed significantly higher achievement and vocabulary size levels for the participants in the experimental group. Certain implications were provided for EFL instructors, material developers and EFL learners who pursue to boost their vocabulary levels more effectively.
\end{abstract}

Key words: Mnemonic, Keyword, Techniques, Efl, Vocabulary, Teaching, Vocabulary Size

\section{BACKGROUND}

Vocabulary is an indispensable aspect of any extended communication and is often considered a more crucial component than structure (Richards and Renandaya, 2002). In the cases that EFL/ESL learners cannot convey their messages across should be omitted in a comprehensible way in either a written or spoken context due to an insufficient level of vocabulary, they lose their interest in furthering their achievement and may become demotivated. Considering this pivotal role of vocabulary, it is much of a surprise that vocabulary instruction has been relatively out of focus in EFL/ESL courses. Due to the fact that vocabulary instruction if treated effectively may be an exhilarating activity for the learners, this level of treatment is not justifiable. Of course, it should be remembered that effective vocabulary teaching is not always a simple and straight process. It often needs preparation in advance on the side of the instructors. Furthermore, it seems that vocabulary teaching techniques need more attention due to their essential roles in communication (Barani \& Seyyedrezaie, 2013). Three lines of argument are suggested for the dilapidated state of vocabulary instruction in EFL/ESL contexts:

a) A policy of focusing more on grammar at the expense of vocabulary has existed in EFL/ESL communities.

b) A certain conviction in EFL pedagogic circles was common according to which learning a large number of words prior to building a solid grammar base would lead to producing too many ungrammatical sentences by the learners. c) The instructors held the position that the real and in depth meaning of vocabulary items are not teachable and have to be mastered by the learners independently (French 1983).

This atmosphere has currently changed and there seems to be a revitalization in vocabulary instruction in EFL/ESL circles (Coady and Huckin, 1997; Richards and Renandya, 2002; Hedge, 2008 as cited in Amiryousefi and Ketabi, 2011). One example for such a tendency is Welkin's (1972, as cited in Milton, 2008, p.230) remark that "Without grammar very little can be conveyed, without vocabulary nothing can be conveyed". EFL learners have paid a lot of attention and interest to this aspect of second or foreign language learning. Consequently, many researchers have conducted extensive research projects on different aspects of vocabulary instruction (Freihat \& Al-Makhzoomi,2012). Having a good command of the nuances of words including their collocations and occasions of use is a important side of vocabulary learning (Willis 1990; Nattinger \& DeCarrico 1992). Different EFL/ESL approaches enjoy the particularities when it comes to vocabulary teaching but the fact of the matter is that there have been periods of extreme attention or total ignorance when it comes to vocabulary instruction in EFL/ESL settings (Schmitt 2000). An acceptable level of vocabulary size has been unanimously considered as one of the components of communicative competence and a part and parcel of EFL/ESL learning (McCrostie (2007). Moreover, Nation and Waring (1997) put forward the argument 
that the knowledge of vocabulary should be considered as one of the separate language skills in terms of importance. Using the same line of argument, Wallace (1982) held that a large enough competency in vocabulary is an inseparable aspect of any effective communication in EFL/ESL setting. From yet another perspective, Sorayaie Azar (2012) asserts that vocabulary knowledge in a foreign language can be described as a binding for all the language skills and developing a good enough vocabulary mastery is essential in learning a foreign language.

\section{Mnemonic Techniques}

Many methodology scholars have had attempts to come up with the best instructional procedures that lead to more effective vocabulary learning and achievement in a second or foreign language. Certain vocabulary learning and teaching techniques which are covered under the general term of mnemonic methods refer to some ways of boosting learning and recall of vocabulary items that are routed in ancient civilizations of the old world (Siriganjanavong, 2013). Solso (1995; as cited in Pillai, 2017) defines mnemonic methods as "techniques or devices, such as a rhyme or an image, that serve to enhance the storage and the recall of information contained in memory and they can be either verbal or visual in nature" (p. 62).

A brief description of this vocabulary teaching omit the plural s of procedures follows (Kasper, 1993). The first step is initiated by the language learners. They are supposed to find some key words in the second or foreign language, which are similar or identical in terms of the way they are pronounced to their first language. Next, it should be reminded that this can be a very creative and individualistic process that provides room for every language learner to show off his or her own choices. The learners should find a relevant keyword that is to some extent a homophone of a word in their own first language. For instance, feel (the verb in English) is a homophone for an animal name in Persian with the same sound (elephant). The students are supposed to make a sentence that involves some kind of imagery using the English word and its Persian homophone translated into English. A suggested sentence could be the following: "I feel the extraordinary power of the elephant when I go to the zoo at weekend. As an extra activity, the students can draw the pictures that represent the content of the sentence in a graphic way. This can be a particularly entertaining and effective technique for young adults and children. It provides them with an outlet to show their artistic sides as well. Yet another technique, which may suit certain age groups of learners or vocabulary items, is dramatizing the sentences and creating mini place. Furthermore, the students especially at intermediate or higher level of proficiency can be encouraged to write short or mini stories using a number of mnemonically boosted items of vocabulary in a creative and entertaining context. More explanation of this procedure is provided in the next section on vocabulary size.

Figure 1 illustrates steps in performing one of the commonly used mnemonic strategies in teaching and learning vocabulary referred to as the keyword technic.

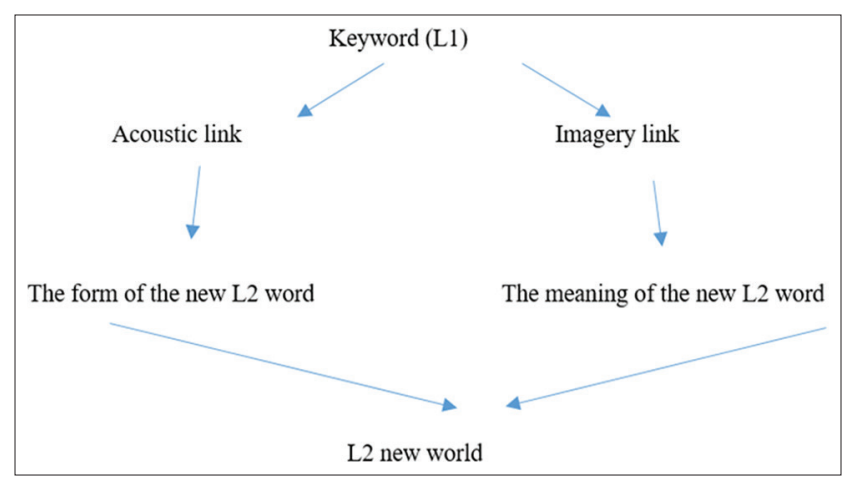

Figure 1. The parts of the keyword technique. (Wei, 2014, p.2)

\section{Vocabulary Size}

The development of Vocabulary Level Test by Paul Nation (1990) may be considered one of the most significant breakthroughs in the research on ESL vocabulary acquisition over the past few decades (Meara, 2016). The result of the test leads to a score, which is an estimation of the learner's vocabulary size. This test has the benefit of being easy to follow and administer on a large scale. That is why it has been used as a research tool and vocabulary assessment test in many parts of the world since its first version was introduced in 1990. One of the popular research issues that has frequently taken benefit of this test is examining the mutual relationship between reading ability and vocabulary size in ESL. It should be noted, however, that many extended issues in ESL research have also been based on the use of this test by many scholars. Some of this research areas include the dynamic relationship between receptive and productive vocabulary levels. Although such distinction has often been considered in a very superficial way in different textbooks on fundamentals of second language acquisition and also EFL/ESL textbooks which are specifically designed for vocabulary instruction, there seems to be some gaps in empirical research in those areas. Nation has addressed this need frequently in his works on vocabulary acquisition over many years (Nation, 1992; Hirsh and Nation 1992; Nation and Waring, 1997; Laufer and Nation, 1999). As for the textbook writers, some simplify the distinction between passive and active vocabulary to just including separate lists for them in the main textbook or the accompanying workbooks (Meara, 2016). Regardless of the fact that a considerable number of research projects have had their foci on passive active vocabulary in EFL/ESL context (Corson, 1983, 1995; Laufer, 1998; Melka-Teichroew, 1982,1997; Lee, 2003; Lee and Muncie, 2006), it is still not a clear-cut one. Perhaps one of the major explanations for this state is the challenge that exists in developing psychometrically valid and reliable vocabulary size tests, which look friendly to the learners at the same time. Therefore, it is not such a major revelation that most researchers have adapted the original Vocabulary Level Test (Nation, 1990) both for productive and receptive assessment purposes. It should be noted, however, that the interpretation of the productive level tests are more complicated than the passive ones. This means one of the research agendas facing the keen research- 
ers in this area should be developing other tests for gauging productive vocabulary size in EFL/ESL contexts.

Based on these issues, this research tried to find answers to the following questions:

1. Is there any statically significant difference between the Iranian EFL learners instructed vocabulary through mnemonic techniques and the ones taught vocabulary through conventional ways in their vocabulary achievement scores?

2. Is there any statistically significant difference between the Iranian EFL learners instructed vocabulary through mnemonic techniques and the ones taught vocabulary through conventional ways in their vocabulary size scores?

It should be noted that based on the existing inconclusive literature on this research two null hypotheses were formed.

\section{METHOD}

The design of this study was of the quasi-experimental type. The reason for this was the fact that no randomization took place for choosing the participants and they were included based on their availability for the researcher. Figure 2 represents a schematic view of the design.

Two groups of students, who were available to the researcher in Aryan Poor English language institute (Tehran, Iran) over two summer semesters in 2017, were given a sample of OPT (Oxford Placement Test, 2001) proficiency test. Based on the results of the test, out of the original 82 students, 70 of them were tagged as intermediate EFL learners who composed the control and experimental groups for this study. All of the students were female with the age range of 18 to 41 . Furthermore, the level of their education ranged from high-school diploma to $\mathrm{PhD}$ and medical degrees.

A number of tests were used during the different phases of this study including versions A and B of productive vocabulary size test (Laufer \& Nation) available at https:// www.lextutor.ca/tests/levels/productive. The reliability indices for version $\mathrm{A}$ and $\mathrm{B}$ were estimated to be 0.80 and 0.76 respectively. Moreover, a vocabulary achievement test based on Top Notch (2006) volume 3(units 1 to 5) was adapted from the series test book. The reliability index of the test was estimated as 0.91 .It included 40 multiple-choice items. Furthermore, Top Notch volume 3 was used as the platform for selecting and teaching the items based on the fact that it was the textbook for the institute.

In the current research, the researchers trained the intermediate Iranian EFL learners in the experimental group to use some new items of vocabulary in each unit of their textbook for creating their own idiosyncratic versions of English sentences in which English words are accompanied by their translated

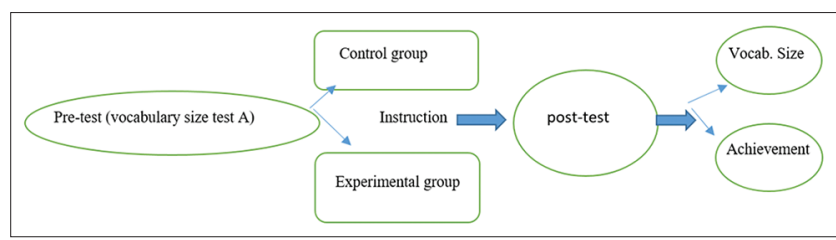

Figure 2. Design of the study mnemonic counterparts. Every other session the learners also provided mini stories that contained a number of mnemonically boosted items of English vocabulary. The intermediate EFL students in the control group were taught the same units of the textbook with the difference of receiving vocabulary instruction through conventional techniques including definitions, synonyms/antonyms, vocabulary maps, and occasional translation. The total instruction time for both groups was 45 hours which was distributed over 30 sessions. It should be noted that vocabulary instruction activities that were the foci of this research varied between 15 and 25 minutes depending on the volume of the vocabulary taught and its related activates.

The obtained scores from different tests including the vocabulary size test and vocabulary achievement tests were analyzed using two independent sample T- tests and two paired sample T-tests. To make sure that the assumptions for the parametric tests exist in the samples, normality test were also conducted before running the T-test.

\section{RESULTS AND DISCUSSION}

The results are presented in the following sequence starting with the normality test tables using Kolmogorov-Smirnov ${ }^{\text {a }}$ tests for each sets of test scores in different phases. Next come the inferential statistics including T-tests for testing null hypotheses 1 and 2 which were proposed based on the initially posed questions. The last section puts forward a number of arguments to explain the results along with some implications which could be driven from this research. Table 1 presents the results of the normality tests for vocabulary size and achievement tests.

Results on table 1 illustrate the fact that the levels of significance ( 0.34 and 0.44 ) are more than 0.5 . In other words, the existing distribution can be considered as normal. The next part of the results deals with the first hypothesis, which was tested by an independent sample t-test the results of which comes on tables 2 and 3 .

As the statistics on table 3 illustrate, the $t$ index (8.56) is significant at 0.000 . In other words, the null hypothesis was rejected and an alternative hypothesis replaced it; there is a significant difference between the Iranian EFL learners instructed vocabulary through mnemonic techniques and the ones taught vocabulary through conventional ways in their vocabulary achievement scores.

The second hypothesis was tested using two independent T-tests. Tables 4 to 7 include the results. Tables 4 and 5 illus-

Table 1. Normality test results for the productive vocabulary tests version A, B and achievement test

\begin{tabular}{lccc}
\hline Group & \multicolumn{3}{c}{ Shapiro-Wilk } \\
\cline { 2 - 4 } & Statistic & df & Sig. \\
\hline Experimental & 0.966 & 35 & 0.342 \\
Control & 0.970 & 35 & 0.441 \\
Experimental & 0.943 & 35 & 0.067 \\
Control & 0.945 & 35 & 0.081 \\
Experimental & 0.957 & 35 & 0.191 \\
Control & 0.952 & 35 & 0.126 \\
\hline
\end{tabular}

*. This is a lower bound of the true significance. 
trate the results of the pretest for vocabulary size test for the participants in both groups.

Table 5 shows that the T index $(0.048)$ is not significant (Sig. 0.962 ) and the EFL learners' scores can be assumed to be equal.

Tables 6 and 7 represent the comparative results of the posttest for vocabulary size test which was taken after the instruction period.

According to table 7, the $\mathrm{T}$ index (27.229) is significant (Sig. 0.000). Therefore, the second null hypothesis was also strongly rejected and an alternative hypothesis was adopt- ed: There is a significant difference between the Iranian EFL learners instructed vocabulary through mnemonic techniques and the ones taught vocabulary through conventional ways in their vocabulary size test scores.

\section{DISCUSSION AND IMPLICATIONS}

The results of this study are in line with Karami (2014). One of the major differences between the present study and the similar ones in the EFL context, however, is that the instruction period

Table 2. General statistics for the independent sample t-test results for the achievement test comparing the control and experimental groups

\begin{tabular}{lllccr}
\hline & Group & N & Mean & Std. deviation & Std. error mean \\
\hline Vocab. Achiev. Test & Experiment. & 35 & 74.91 & 2.548 & 0.431 \\
& Control & 35 & 69.66 & 2.589 & 0.438 \\
\hline
\end{tabular}

Table 3. Results for the independent sample T-test results for the vocabulary achievement test comparing the control and experimental groups

\begin{tabular}{|c|c|c|c|c|c|c|c|c|c|}
\hline \multirow[t]{3}{*}{$\begin{array}{l}\text { Vocab. } \\
\text { Achieve. test }\end{array}$} & \multicolumn{2}{|c|}{$\begin{array}{l}\text { Levene's test } \\
\text { for equality of } \\
\text { variances }\end{array}$} & \multicolumn{7}{|c|}{ t-test for equality of means } \\
\hline & \multirow[t]{2}{*}{$\mathbf{F}$} & \multirow[t]{2}{*}{ Sig. } & \multirow[t]{2}{*}{$\mathbf{t}$} & \multirow[t]{2}{*}{ df } & \multirow[t]{2}{*}{ Sig. (2-tailed) } & \multirow[t]{2}{*}{$\begin{array}{c}\text { Mean } \\
\text { difference }\end{array}$} & \multirow[t]{2}{*}{$\begin{array}{l}\text { Std. error } \\
\text { difference }\end{array}$} & \multicolumn{2}{|c|}{$\begin{array}{l}95 \% \text { confidence } \\
\text { interval of the } \\
\text { difference }\end{array}$} \\
\hline & & & & & & & & Lower & Upper \\
\hline $\begin{array}{l}\text { Equal } \\
\text { variances } \\
\text { assumed }\end{array}$ & 0.029 & 0.865 & 8.562 & 68 & 0.000 & 5.257 & 0.614 & 4.032 & 6.482 \\
\hline
\end{tabular}

Table 4. General statistics for the independent sample t-test results for the vocabulary size test version A comparing the control and experimental groups

\begin{tabular}{lllccr}
\hline & Group & N & Mean & Std. deviation & Std. error mean \\
\hline Vocab. Size Pretest & Experiment. & 35 & 24.54 & 2.466 & 0.417 \\
& Control & 35 & 24.57 & 2.535 & 0.429 \\
\hline
\end{tabular}

Table 5. Results for the independent sample t-test comparing the control and experimental groups scores on vocabulary size pretest (Version A)

\begin{tabular}{|c|c|c|c|c|c|c|c|c|c|}
\hline \multirow[t]{3}{*}{ Vocab. Size pretest } & \multicolumn{2}{|c|}{$\begin{array}{c}\text { Levene's test } \\
\text { for equality of } \\
\text { variances } \\
\end{array}$} & \multicolumn{7}{|c|}{ t-test for equality of means } \\
\hline & \multirow[t]{2}{*}{$\mathbf{F}$} & \multirow[t]{2}{*}{ Sig. } & \multirow[t]{2}{*}{$\mathbf{t}$} & \multirow[t]{2}{*}{ df } & \multirow[t]{2}{*}{ Sig. (2-tailed) } & \multirow[t]{2}{*}{$\begin{array}{l}\text { Mean } \\
\text { difference }\end{array}$} & \multirow[t]{2}{*}{$\begin{array}{l}\text { Std. error } \\
\text { difference }\end{array}$} & \multicolumn{2}{|c|}{$\begin{array}{c}95 \% \text { confidence } \\
\text { interval of the } \\
\text { difference }\end{array}$} \\
\hline & & & & & & & & Lower & Upper \\
\hline Equal variances assumed & 0.026 & 0.873 & -0.048 & 68 & 0.962 & -0.029 & 0.598 & -1.221 & 1.164 \\
\hline
\end{tabular}

Table 6. General Statistics for the independent sample t-test results for the vocabulary size post-test version B comparing the control and experimental groups

\begin{tabular}{lllccr}
\hline & Group & N & Mean & Std. deviation & Std. error mean \\
\hline Vocab. size post-test & Experiment. & 35 & 45.40 & 1.519 & 0.257 \\
& Control & 35 & 34.83 & 1.723 & 0.291 \\
\hline
\end{tabular}


Table 7.General statistics for the independent sample T-test results for the vocabulary size post-test version B comparing the control and experimental groups

\begin{tabular}{|c|c|c|c|c|c|c|c|c|c|}
\hline \multirow[t]{3}{*}{$\begin{array}{l}\text { Vocab. } \\
\text { size post-test }\end{array}$} & \multicolumn{4}{|c|}{$\begin{array}{l}\text { Levene's test } \\
\text { for equality of } \\
\text { variances }\end{array}$} & \multicolumn{5}{|c|}{ t-test for equality of means } \\
\hline & \multirow[t]{2}{*}{$\mathbf{F}$} & \multirow[t]{2}{*}{ Sig. } & \multirow[t]{2}{*}{$\mathbf{t}$} & \multirow[t]{2}{*}{ df } & \multirow[t]{2}{*}{ Sig. (2-tailed) } & \multirow[t]{2}{*}{$\begin{array}{l}\text { Mean } \\
\text { difference }\end{array}$} & \multirow[t]{2}{*}{$\begin{array}{l}\text { Std. error } \\
\text { difference }\end{array}$} & \multicolumn{2}{|c|}{$\begin{array}{l}95 \% \text { confidence } \\
\text { interval of the } \\
\text { difference }\end{array}$} \\
\hline & & & & & & & & Lower & Upper \\
\hline Equal variances assumed & 0.348 & 0.557 & 27.229 & 68 & 0.000 & 10.571 & 0.388 & 9.797 & 11.346 \\
\hline
\end{tabular}

was extended to two semesters or 3 months. The findings on vocabulary size improvement are also divergent from many similar studies including Qoreishi (2014) and Manshourian (2016) among others. Some lines of argument can be suggested for different aspects of the results firstly the significant improvement in the vocabulary size of the EFL learners in the experimental group may be due to the regular application of the mnemonic techniques at the vocabulary learning level to a more contextualized setting which was writing mini-stories. In other words, the students had to write stories and include the vocabulary items from mnemonically learned setting to a wider context that needed extra vocabulary to cement the narrative. The students might have resorted to checking dictionaries or other resources to form the narrative. Secondly, the significantly higher level of achievement may be partly explained in terms of Gardner's (2011) multiple intelligence theory. The fact that students in the experimental group were encouraged to form imageries for certain items of vocabulary might have boosted their visual intelligence compared to the other students. This might have contributed to their significantly better scores on the vocabulary test. Finally, the more entertaining and novel features in the mnemonic techniques might explain overall better performance of the EFL learners on both achievement and vocabulary size tests. This was witnessed by the positive feedback the instructor got from the learners while teaching vocabulary through mnemonic techniques.

Certain stakeholders can benefits from the findings of this study. First and foremost, the EFL learners may enhance their vocabulary achievement and acquisition levels by applying different mnemonic procedures some of which were extensively used in this research. Next, EFL/ESL instructors who are looking for some novel and effective ways in vocabulary teaching may consider using the wide array of mnemonic techniques and some their related activities such as creative mini story writing and drama performances in their classes. Last but not least, material developers either in the capacity of publishers or at a limited scale in a language institute can consider preparing supplementary materials that are closely based on the idea of mnemonic representation of vocabulary items for the already available textbooks.

\section{REFERENCES}

Amiryousefi, M., \& Ketabi, S. (2011). Mnemonic Instruction: A Way to Boost Vocabulary Learning and Recall. Journal of Language Teaching \& Research, 2(1).
Coady, J., \& Huckin, T. (1997). Second language vocabulary acquisition: A rationale for pedagogy. Cambridge University Press.

Corson, D. J. (1983). The Corson measure of passive vocabulary. Language and Speech, 26(1), 3-20.

Corson, D. (1997). The learning and use of academic English words. Language learning, 47(4), 671-718.

Freihat, S., \& Al-Makhzoomi, K. (2012). An English for Specific Purposes (ESP) course for nursing students in jordan and the role a needs analysis played. International Journal of Humanities and Social Science, 2(7), 129-145.

French-Allen, V. (1983). Techniques in teaching vocabulary. Oxford University Press.

Gardner, H. (2011). Frames of mind: The theory of multiple intelligences. Basic books.

Hirsh, D., \& Nation, P. (1992). What vocabulary size is needed to read unsimplified texts for pleasure? Reading in a foreign language, 8, 689-689.

Karami, M. (2014). The Effect of Extended Mnemonic Keyword Method on Vocabulary Achievement and Expansion among Iranian EFL Learners: A thesis in teaching English to speakers of other languages (master's thesis). IAU, Bandar Abbas, Iran.

Kasper, L. F. (1993). The keyword method and foreign language vocabulary learning: A rationale for its use. Foreign Language Annals, 26(2), 244-251.

Laufer, B. (1998). The development of passive and active vocabulary in a second language: same or different?. Applied linguistics, 19(2), 255-271

Laufer, B., \& Nation, P. (1999). A vocabulary-size test of controlled productive ability. Language testing, 16(1), 33-51.

Lee, S. H. (2003). ESL learners' vocabulary use in writing and the effects of explicit vocabulary instruction. System, 31(4), 537-561.

Lee, S. H., \& Muncie, J. (2006). From receptive to productive: Improving ESL learners' use of vocabulary in a postreading composition task. Tesol Quarterly, 40(2), 295-320.

Manshourian, F. (2016).Conventional Techniques of Vocabulary Teaching vs. Novel Mnemonic Keyword Procedure: The Case of Vocabulary Achievement and Vocabulary Size among Iranian EFL Learners: A thesis in teaching English to speakers of other languages (master's thesis). Alborz University, Qazvin, Iran. 
McCrostie, J. (2007). Examining learner vocabulary notebooks. ELT journal, 61(3), 246-255.

Meara, P., \& Miralpeix, I. (2016). Tools for researching vocabulary (Vol. 105). Multilingual Matters.

Melka-Teichroew, F. (1982). Receptive versus productive vocabulary: A survey. Inter language Studies Bulletin, 5-33.

Melka-Teichroew, F. (1997). Receptive vs. productive aspects of vocabulary. Vocabulary: Description, acquisition and pedagogy, 33(2), 84-102.

Milton, J. (2008). Vocabulary uptake from informal learning tasks. Language Learning Journal, 36(2), 227-237.

Nation, P., \& Waring, R. (1997). Vocabulary size, text coverage and word lists. Vocabulary: Description, acquisition and pedagogy, 14, 6-19.

Nattinger, J. R., \& DeCarrico, J. S. (1992). Lexical phrases and language teaching. Oxford University Press.

Pillai, N. R. (2017). Using mnemonics to improve vocabulary, boost memory and enhance creativity in the ESL classroom. The English Teacher, 22.

Qoreishi, A. (2014).The Impact of Mind Mapping On Vocabulary Achievement of Iranian EFL Learners in Pooya
Language Institute in Bandar Abbas: A thesis in teaching English to speakers of other languages (master's thesis). IAU, Bandar Abbas, Iran.

Richards, J. C., \& Renandya, W. A. (Eds.). (2002). Methodology in language teaching: An anthology of current practice. Cambridge university press.

Saslow, J. M., Ascher, A., \& Morsberger, R. E. (2006). Top Notch: English for today's world 2. Pearson Longman.

Schmitt, N. (2000). Vocabulary in language teaching. Ernst Klett Sprachen.

Seyyedrezaie, S. H., \& Barani, G. (2013). Constructivism and Curriculum Development. International Journal of Basic \& Applied Research, 2(1), 62-67.

Siriganjanavong, V. (2013). The Mnemonic Keyword Method: Effects on the Vocabulary Acquisition and Retention. English Language Teaching, 6(10), 1-10.

Sorayaie Azar, A. (2012). The effect of games on EFL learners' vocabulary learning strategies. International Journal of Basic and Applied Science, 1(02), 252-256.

Wallace, M. J. (1982). Teaching vocabulary (No. 10). Heinemann. Willis, D. (1990). The lexical syllabus. London: Collins. 